DOI: https://doi.org/10.24127/ajpm.v10i2.3482

\title{
KEMAMPUAN PEMECAHAN MASALAH GEOMETRI BIDANG DITINJAU DOMINASI OTAK KIRI MAHASISWA
}

\author{
Winda Nur Zahuroh ${ }^{1}$, Rita Pramujiyanti Khotimah ${ }^{2^{*}}$ \\ ${ }^{1,2 *}$ Universitas Muhammadiyah Surakarta, Surakarta, Indonesia \\ *Corresponding author. \\ Email : $\frac{\text { windanur2015@gmail.com }{ }^{l)}}{\left.\text { rpramujivanti@ums.ac.id }{ }^{2}\right)}$
}

Received 16 January 2021; Received in revised form 21 June 2021; Accepted 28 June 2021

\begin{abstract}
Abstrak
Penelitian ini bertujuan untuk menganalisis dan mendeskripsikan kemampuan pemecahan masalah mahasiswa dalam menyelesaikan soal geometri bidang berdasarkan langkah Polya ditinjau dari dominasi otak kiri. Jenis penelitian ini adalah kualitatif dengan pendekatan studi kasus, dan mengambil dua subjek dari kelas 1E Program Studi Pendidikan Matematika Universitas Muhammadiyah Surakarta. Teknik pengumpulan data yang digunakan dalam penelitian ini adalah dokumentasi, tes, dan wawancara. Keabsahan data dilakukan dengan triangulasi teknik. Berdasarkan hasil penelitian diperoleh kemampuan pemecahan masalah mahasiswa sebagai berikut: (1) Memahami masalah: Kedua mahasiswa dominan otak kiri mampu memahami permasalahan pada seluruh nomor. (2) Merencanakan: Kedua mahasiswa dominan otak kiri mampu merencanakan seluruh nomor. (3) Melaksanakan: Kedua mahasiswa dominan otak kiri tidak mampu melaksanakan soal nomor satu tetapi mampu melaksanakan soal nomor dua. (4) Melihat kembali: Salah satu mahasiswa dominan otak kiri tidak melihat kembali pada soal nomor satu tetapi melihat kembali pada soal nomor dua. Sedangkan mahasiswa dominan otak kiri yang lain tidak melihat kembali seluruh nomor.
\end{abstract}

Kata Kunci: Dominan otak kiri; geometri bidang; pemecahan masalah; Polya.

\begin{abstract}
This study aims to analyze and describe the students' problem-solving abilities in solving plane geometry problems based on Polya's steps in terms of the dominance of the left brain. This type of research is qualitative with a case study approach, and takes two subjects randomly from class $1 E$ Muhammadiyah University of Surakarta. Data collection techniques used in this study were documentation of the results of midterm exams, brain domination tests, and interviews. The validity of the data used in this study was triangulating technique by comparing the documentation of the results of midterm exams, brain dominance tests, and interviews. Based on data analysis and discussion obtained: (1) Understanding the problems: The two of dominance left brain's student was able to understanding problems in all numbers. (2) Devise a plan: The two of dominance left brain's student was able to understanding problems in all numbers. (3) Carry out the plan: The two of dominance left brain's student was not able to carry out the plan in number one but it was able to carry out the plan in number two. (4) Look back: The dominance left brain's student did not look back at question number but looked back at number two. Meanwhile the other dominance left brain's student did not look back at the whole number.
\end{abstract}

Keywords: Left brain dominance; plane geometry; problem solving; Polya.

This is an open access article under the Creative Commons Attribution 4.0 International License

PENDAHULUAN

Perbincangan

mengenai keseimbangan otak kanan dan otak kiri manusia terus menjadi pokok bahasan pada pada bidang penelitian otak dan ilmu syaraf. Beberapa penelitian menunjukkan bahwa orang biasanya lebih menyukai penggunaan satu sisi otak mereka daripada sisi lainnya (Belecina \& Ocampo, 2019). Beberapa 
ilmuwan juga berpendapat bahwa otak kiri lebih diuntungkan pada sesuatu yang terstruktur seperti pada pelajaran matematika di mana terdapat banyak konsep dan perhitungan di dalamnya.

Matematika masih sering menjadi momok bagi siswa, banyak siswa yang merasa bahwa matematika itu sulit padahal matematika merupakan salah satu mata pelajaran yang wajib dipelajari oleh siswa pada setiap jenjang pendidikan. Laurens et al. (2018) menyatakan bahwa beberapa pelajar masih merasa takut menghadapi kesulitan dalam belajar matematika.

Salah satu materi di dalam matematika yang sulit dipahami oleh siswa adalah geometri bidang, di mana materi di dalam geometri bidang ini sangat berhubungan erat dengan kehidupan nyata sehari-hari. Untuk dapat menyelesaikan soal-soal matematika terutama pada geometri bidang, kemampuan pemecahan masalah siswa sangat diperlukan.

Kemampuan pemecahan masalah yang baik sangat diperlukan oleh siswa dalam menyelesaikan masalah-masalah yang diberikan. Selain itu, melalui kemampuan pemecahan masalah yang dimilikinya, siswa akan bisa mengembangkan ketrampilan berpikirnya (Gunawan, 2019). Banyak permasalahan dalam kehidupan seharihari yang memerlukan kemampuan pemecahan masalah (Yohanes, 2012).

Kemampuan pemecahan masalah perlu diajarkan kepada siswa mengingat pentingnya peranan matematika untuk menyelesaikan masalah sehari-hari. Kemampuan pemecahan masalah berhubungan dengan kemampuan siswa dalam memahami masalah yang biasanya dalam bentuk soal cerita, merumuskan model matematika dari permasalahan yang diketahui, membuat perencanaan, serta penyelesaian soal- soal non rutin. Kemampuan komunikasi matematika yang baik, adanya interaksi antar siswa, dan interaksi siswa dengan guru sangat diperlukan dalam pemecahan masalah (Anisa, 2014).

Beberapa penelitian yang berkaitan dengan kemampuan pemecahan masalah menyatakan bahwa pelajar dari berbagai jenjang perlu berlatih untuk meningkatkan kemampuannya dalam memecahkan masalah sehingga tujuan pembelajaran akan tercapai (Ninik, Hobri, 2016; Yuwono, Supanggih, \& Ferdiani, 2018; Gunawan, 2019). Namun, dari penelitian-penelitian tersebut, belum banyak yang meneliti tentang kemampuan pemecahan masalah pada materi geometri bidang ditinjau dari dominan otak kiri.

Pola pikir siswa saat belajar, ketika memecahkan masalah, dan saat proses berpikir, banyak dipengaruhi oleh dominasi otak kiri. Oleh karena itu, perlu diadakan penelitian untuk mencari tahu bagaimana kemampuan pemecahan masalah mahasiswa dengan dominan otak kiri dalam mengerjakan soal geometri bidang dengan langkah polya sehingga dapat menentukan strategi yang dapat digunakan agar pelajar lebih mudah memahami konsep matematika terutama untuk mahasiswa yang memiliki dominan otak kiri yang seharusnya lebih unggul dalam matematika serta menghilangkan momok menakutkan dari matematika tersebut. Berdasarkan uraian di atas penelitian ini bertujuan untuk menganalisis kemampuan pemecahan masalah mahasiswa dalam menyelesaikan soal geometri bidang ditinjau dari dominan otak kiri.

\section{METODE PENELITIAN}

Jenis penelitian ini berdasarkan pendekatannya merupakan penelitian 
kualitatif. Populasi dalam penelitian ini adalah 21 mahasiswa kelas 1E Universitas Muhammadiyah Surakarta. Teknik pengambilan subjek menggunakan teknik purposive sampling dimana subjek yang memperoleh skor tes dominasi otak yang paling tinggi yaitu skor 3,5 dan 4 dari skala penilaian 1 sampai 5 , sehingga diperoleh 2 mahasiswa yang dijadikan sebagai subjek berdasarkan skor terbanyak yang diperoleh. Pengumpulan data dalam penelitian ini menggunakan dokumentasi hasil ujian tengah semester, tes dominasi otak, dan wawancara. Teknis analisis data dilakukan dengan triangulasi teknik, yaitu membandingkan dokumentasi hasil ujian tengah semester, tes dominasi otak, dan wawancara.

\section{HASIL DAN PEMBAHASAN}

Pelaksanaan penelitian dilakukan pada mahasiswa semester 1 kelas $\mathrm{E}$ Program Studi Pendidikan Matematika di Universitas Muhammadiyah Surakarta yang berjumlah 21 orang. Penelitian yang dilaksanakan berupa pemberian tes dominasi otak yang diadaptasi dari Psikobiolog dan pemenang hadiah Nobel yaitu Roger W. Sperry. Tes tersebut berupa pertanyaan yang dibagi menjadi 2 golongan yaitu golongan A (dominan otak kiri) dan golongan B (dominan otak kanan). Masing-masing golongan terdiri dari 10 pertanyaan dan disediakan dua pilihan jawaban yaitu jawaban "YA" atau
"TIDAK". Berdasarkan hasil Tes Dominasi Otak diperoleh 5 mahasiswa dengan kategori dominan otak kiri (DOK). Selanjutnya pengambilan subjek menggunakan teknik purposive sampling, yaitu dipilih subjek yang memperoleh skor tes dominasi otak yang paling tinggi yaitu skor 3,5 dan 4 dari skala penilaian 1 sampai 5 dan diperoleh dua mahasiswa dengan dominan otak kiri sebagai subjek. Adapun dua soal UTS mata kuliah geometri bidang yang digunakan, yaitu:

1) Jika didalam trapesium terdapat dua diagonal yang kongruen maka trapesium tersebut adalah sama kaki. Buktikan pernyataan tersebut.

2) Diberikan sebuah segitiga $\mathrm{ABC}$ dengan besar sudut $\angle \mathrm{BAC}=82.5^{\circ}$, panjang $\mathrm{AB}=\frac{2}{3} \sqrt{173}$ dan panjang $\mathrm{AC}=\frac{4}{7} \sqrt{37}$. Maka:

a. Lukislah segitiga $A B C$ tersebut sesuai dengan ketentuan soal dan tulis langkah-langkahnya.

b. Berapakah panjang BC? (dibulatkan satu angka dibelakang koma)

c. Jika $\mathrm{CD}$ adalah ruas garis tinggi dari segitiga $\mathrm{ABC}$ dengan $\mathrm{AB}$ adalah sisi alas segitiga $\mathrm{ABC}$, maka berapakah panjang CD? (dibulatkan satu angka dibelakang koma)

Deskripsi kemampuan pemecahan masalah mahasiswa dalam menyelesaikan soal geometri bidang ditinjau dari dominasi otak kiri sebagai berikut ditunjukkan pada Tabel 1 .

Tabel 1. Kemampuan pemecahan masalah

\begin{tabular}{ccccccccc}
\hline Indikator & \multicolumn{2}{c}{ Memahami } & \multicolumn{2}{c}{ Merencanakan } & \multicolumn{2}{c}{ Melaksanakan } & \multicolumn{2}{c}{ Melihat Kembali } \\
\hline Nomor Soal & $\mathbf{1}$ & $\mathbf{2}$ & $\mathbf{1}$ & $\mathbf{2}$ & $\mathbf{1}$ & $\mathbf{2}$ & $\mathbf{1}$ & $\mathbf{2}$ \\
\hline Subjek DOK-1 & $\checkmark$ & $\checkmark$ & $\checkmark$ & $\checkmark$ & - & $\checkmark$ & - & $\checkmark$ \\
Subjek DOK-2 & $\checkmark$ & $\checkmark$ & $\checkmark$ & $\checkmark$ & - & $\checkmark$ & - & - \\
\hline
\end{tabular}

Keterangan:

Subjek DOK-1 : Mahasiswa dengan dominan otak kiri 1

Subjek DOK-2 : Mahasiswa dengan dominan otak kiri 2 
DOI: https://doi.org/10.24127/ajpm.v10i2.3482

\section{Kemampuan Pemecahan Masalah} Subjek DOK-1

a. Soal Nomor 1

Hasil pekerjaan subjek DOK-1 dalam menyelesaikan soal geometri bidang nomor 1 dapat dilihat pada Gambar 1.

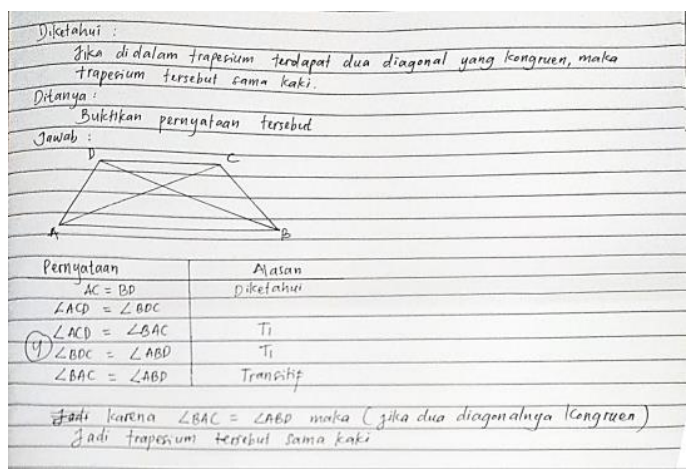

Gambar 1. Hasil pekerjaan subjek DOK-1 nomor 1

Berdasarkan Gambar 1 yang merupakan jawaban dari subjek DOK-1 menunjukkan bahwa subjek tersebut mampu menuliskan informasi penting terkait indikator pertama kemampuan pemecahan masalah menurut teori Polya yaitu memahami masalah seperti hal-hal yang diketahui pada soal dan mampu memahami apa yang ditanyakan dalam soal. Subjek DOK-1 dalam wawancaranya dapat menjelaskan bagaimana bentuk trapesium sama kaki, mengerti apa itu diagonal, mengerti sinonim kata kongruen, dan mengerti cara membuktikan pernyataan yang diketahui dalam soal.

Berbeda dengan indikator kedua dimana subjek DOK-1 dapat membuat rencana penyelesaian dengan baik namun pada indikator ketiga yaitu melaksanakan rencana penyelesaian subjek DOK-1 belum dapat memenuhinya karena rencana yang telah disusun kurang tepat sehingga menyebabkan kesalahan pada proses penyelesaian masalah. Pernyataan tersebut diperkuat dengan dilakukannya wawancara dengan subjek DOK-1 dan diperoleh informasi bahwa subjek DOK-1 tidak mampu untuk melaksanakan rencananya dengan baik. Hal tersebut ditunjukkan dengan tidak diberikannya alasan pada pernyataan yang kedua (pada tabel di lembar jawabnya) karena subjek DOK-1 mengaku lupa akan teorema yang dapat memberikan alasan yang sesuai. Selain itu, subjek DOK-1 memperoleh poin 4 dimana total poin yang dapat diperoleh pada nomer 1 adalah 20 poin. Hal ini berarti pembuktian yang dilakukan oleh subjek DOK-1 kurang tepat. Oleh karena itu, subjek DOK-1 dianggap belum memenuhi indikator ketiga yaitu melaksanakan rencana penyelesaian.

Berdasarkan hasil wawancara dengan subjek DOK-1 dapat dilihat bahwa kemampuan pemecahan masalah subjek DOK-1 belum mampu dalam melaksanakan dan melihat kembali. Dalam melaksanakan rencana, subjek masih belum runtut dalam menuliskan langkah-langkahnya, sehingga jawaban yang dihasilkan kurang tepat. Hasil ini didukung oleh hasil penelitian terdahulu (Pujilestari, 2018), di mana subyek masih banyak melakukan kesalahan pada langkah penyelesaian soal matematika. Tahap melihat kembali juga sering kali diabaikan oleh mahasiswa dikarenakan lupa ataupun tidak mendapatkan waktu yang cukup, nyatanya tahap memahami masalah merupakan tahap yang cukup penting dan berguna. Hal ini juga diungkapkan pada penelitian yang dilakukan oleh (Karlimah, 2010) bahwa pada tahap memeriksa kembali, siswa dapat melakukan kritisasi hasil dengan melihat kelemahan dari solusi yang diterapkan, sehingga kemampuan melihat kembali atau mengecek kembali hasil pekerjaan merupakan langkah terakhir pada langkah Polya yang harus dipenuhi agar mencapai tujuan 
DOI: https://doi.org/10.24127/ajpm.v10i2.3482

pembelajaran yang sesungguhnya. Subjek DOK-1 dalam wawancara mengungkapkan alasannya mengapa tidak melakukan tahap terakhir atau melihat kembali. Subjek DOK-1 menuturkan bahwa ia sudah melakukan pengecekan ulang namun hanya sekilas, yang artinya subjek DOK-1 tidak melakukan kritisasi terhadap hasil pekerjaannya sehingga ia melakukan kesalahan yang mengakibatkannya mendapat skor minimum.

\section{b. Soal Nomor 2}

Contoh hasil pekerjaan subjek DOK1 dalam menyelesaikan soal geometri bidang nomor 2 seperti pada Gambar 2 sampai 4.

\begin{aligned} & \hline Diketahui : Segitiga $A B C \\ &$\hline$\angle B A C=82,5^{\circ} C D=$ ruas garts finggi \\ & \hline$A B=\frac{2}{3} \sqrt{173} A B=$ Alas segitiga \\ & \hline$A C=\frac{4}{7} \sqrt{73} \\ &$\hline Ditanya : \\ & \hline a) Lukis segitiga $A B C$ dan fulis langkahnya \\ & \hline b) Panjang $B C \\ &$\hline c) Panjang (D) \end{aligned}

Gambar 2. Hasil pekerjaan subjek DOK-1 nomor 2

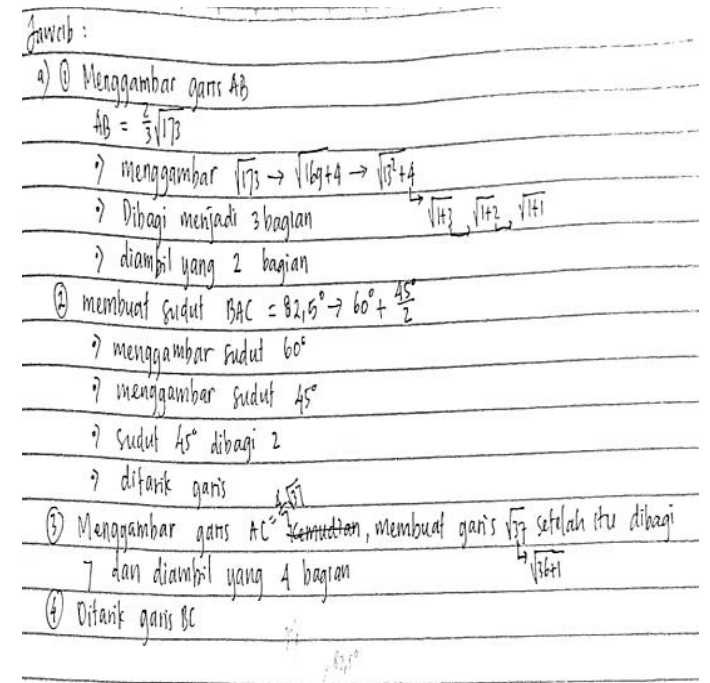

Gambar 3. Hasil pekerjaan subjek DOK-1 nomor 2 bagian A

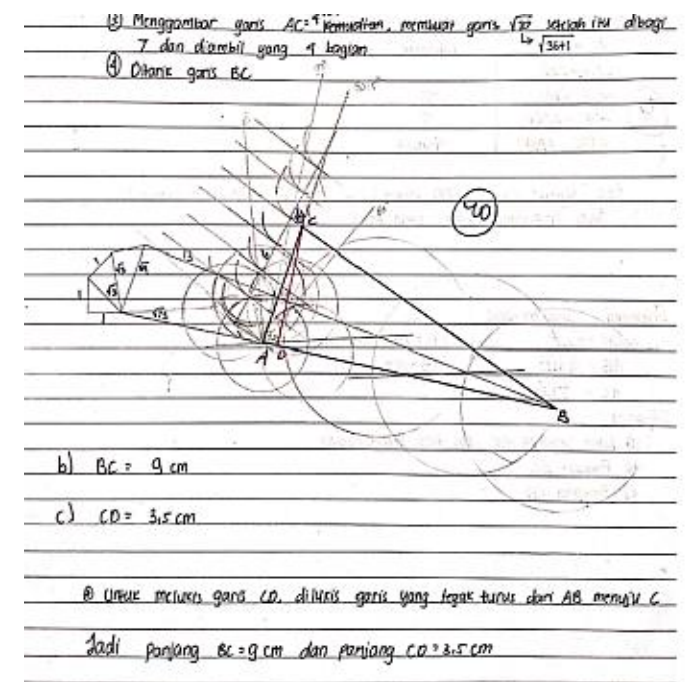

Gambar 4. Hasil pekerjaan subjek DOK-1 nomor 2 bagian B

Subjek DOK-1 pada Gambar 3 menunjukkan bahwa subjek tersebut mampu menuliskan informasi penting terkait indikator pertama kemampuan pemecahan masalah menurut teori Polya yaitu memahami masalah. Informasi penting yang subjek DOK-1 tuliskan berupa hal-hal yang diketahui dan ditanyakan dalam soal di mana hal-hal tersebut memenuhi indikator pertama yaitu memahami masalah. Subjek DOK-1 menuliskan hal-hal yang diketahui berupa segitiga ABC, besar sudut, dan panjang sisi yang diketahui. Oleh karena itu, dapat disimpulkan bahwa subjek DOK-1 telah memenuhi indikator pertama yaitu memahami masalah.

Hal tersebut diperjelas dengan hasil wawancara dengan subjek DOK-1 dan memberikan beberapa informasi terkait dengan indikator-indikator yang terdapat pada poin ini. Informasi yang pertama yaitu subjek DOK-1 dapat menjelaskan bagaimana rencana yang akan dilakukannya untuk mengerjakan soal nomer tiga. Informasi yang kedua, subjek DOK-1 mampu memecahkan masalah sesuai dengan urutan permasalahan dan informasi yang 
diberikan. Ketiga, subjek DOK-1 mampu menyederhanakan permasalahan dengan mengubah angka dari bentuk akar menjadi bilangan yang lebih mudah untuk dilakukan pengukuran. Selanjutnya indikator terakhir dapat ditemukan dalam lembar jawab pada Gambar 4 yang berisi hasil pekerjaan oleh subjek DOK-1 berupa kesimpulan. Kesimpulan yang ditulis oleh subjek DOK-1 tersebut dapat dikatakan sebagai bukti bahwa subjek DOK-1 telah melakukan pengecekan kembali pada jawabannya karena pertanyaan poin $\mathrm{c}$ merupakan lanjutan dari poin-poin sebelumnya di mana jika poin a salah maka poin $b$ dan $c$ juga akan salah.

Berdasarkan hasil wawancara dengan subjek DOK-1 dapat dilihat bahwa kemampuan pemecahan masalah subjek DOK-1 mampu memenuhi seluruh indikator yaitu memahami masalah, menyusun rencana penyelesaian, melaksanakan rencana penyelesaian, dan melihat kembali. Siswa yang dapat menerapkan keempat tahap tersebut akan mencapai proses belajar yang baik yang pada akhirnya memberikan hasil yang baik pula. Namun, meskipun menurut (Demircioğlu, Argün, \& Bulut, 2010) yang menjelaskan bahwa kemampuan pemecahan masalah merupakan tujuan umum pembelajaran matematika bahkan sebagai jantungnya matematika, kebanyakan mahasiswa masih kurang mampu dalam memecahkan masalah. Subjek DOK-1 mampu memenuhi seluruh langkah Polya, yang artinya subjek DOK-1 dalam mengerjakan soal nomor dua sudah mencapai tujuan umum dari pembelajaran matematika. Subjek DOK-1 merupakan salah satu contoh subjek yang memiliki kemampuan pemecahan masalah yang baik karena mampu memenuhi seluruh indikator atau tahap berdasarkan teori Polya. Selain itu, subjek DOK-1 juga merupakan salah satu subjek dominan otak kiri yang mengerjakan soal secara sistematis dan berurutan. Hal ini sesuai dengan penelitian yang dilakukan oleh (Yohanes, 2012) bahwa siswa yang dominan otak kiri cenderung berpikir sistematis, terstruktur, linier, analitik, verbal, parsial. Berdasarkan hal tersebut subjek dengan dominan otak kiri seharusnya lebih diuntungkan dalam matematika. Namun, dalam hal ini keseimbangan otak juga diperlukan agar memperoleh hasil yang maksimal.

2. Kemampuan Pemecahan Masalah Subjek DOK-2

a. Soal Nomor 1

Contoh hasil pekerjaan subjek DOK-

2 dalam menyelesaikan soal geometri bidang nomor 1 terlihat pada Gambar 5 .

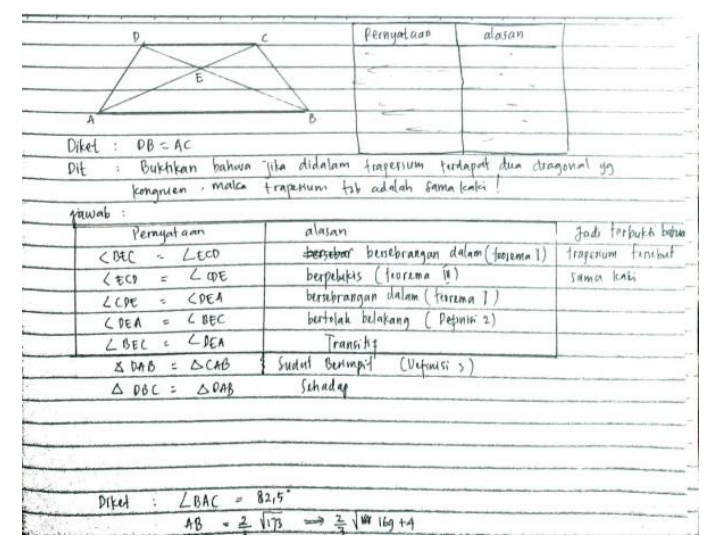

Gambar 5. Hasil pekerjaan subjek DOK-2 nomor 1

Memahami masalah mencakup beberapa aspek diantaranya berupa informasi yang terdapat pada soal yakni hal-hal yang diketahui dan hal-hal yang ditanyakan dalam soal. Subjek DOK-2 harus melaksanakan kedua aspek tersebut agar memenuhi indikator yang pertama ini yaitu memahami masalah. Berdasarkan pada Gambar 5 yang merupakan lembar jawab subjek DOK-2 
telah menuliskan hal-hal yang diketahui dan ditanyakan dalam soal seperti $\mathrm{DB}=\mathrm{AC}$ dimana keduanya merupakan diagonal yang kongruen pada trapesium sama kaki. Hal itu berarti subjek DOK2 memahami tantang dua garis yang kongruen dan memahami bagaimana bentuk dari trapesium sama kaki. Oleh karena itu, subjek DOK-2 memenuhi indikator pertama yaitu memahami masalah.

Langkah berikutnya setelah memahami masalah yaitu subjek DOK2 harus mampu membuat rencana untuk menyelesaikan permasalahan pada soal yang merupakan indikator kedua. Jika dilihat pada lembar jawab subjek DOK2 , terdapat gambar trapesium sama kaki dengan dua diagonal seperti petunjuk dalam soal, dan tabel berupa cara yang digunakan subjek DOK-2 untuk menyelesaikan soal nomer satu. Subjek DOK-2 dalam wawacaranya menjelaskan cara yang digunakan untuk menyelesaikan permasalahan dalam soal. Subjek DOK-2 menjelaskan secara rinci bagaimana ia menyelesaikan soal tersebut mulai dari menggambar trapesium sama kaki dengan dua diagonal yang kongruen hingga memberikan nama pada masing-masing titik. Subjek DOK-2 menyusun rencana penyelesaian dengan baik dan terstruktur. Oleh karena itu, subjek DOK-2 memenuhi indikator kedua yaitu membuat rencana penyelesaian.

Subjek DOK-2 mampu memenuhi dua indikator sebelumnya yaitu indikator pertama memahami masalah dan indikator kedua menyusun rencana penyelesaian, namun pada indikator ketiga yaitu melaksanakan rencana penyelesaian subjek DOK-2 belum mampu untuk memenuhinya. Hal tersebut dikarenakan kekeliruan pada teorema atau cara yang digunakan dalam rencananya sebelum mengerjakan soal meskipun rencana yang telah disusunnya cukup baik sehingga subjek DOK-2 memperoleh skor minimum dari yang seharusnya diperoleh. Subjek DOK-2 dalam kutipan wawancara sebelumnya menyebutkan bahwa ada cara lain yang dapat digunakan yaitu cara kekongruensinan di mana materi itu disampaikan setelah materi kesejajaran garis yang memuat teorema-teorema seperti pada soal. Namun, menurut kunci jawaban, cara kongruensi juga kurang tepat. Subjek DOK-2 seharusnya hanya fokus pada salah satu clue yang disediakan pada soal yaitu dua diagonal yang kongruen. Subjek DOK-2 bahkan sudah menuliskan $\mathrm{DB}=\mathrm{AC}$ sebagai hal yang diketahui namun subjek DOK-2 hanya menganggap bahwa clue tersebut sekedar informasi yang diketahui.

Subjek DOK-2 dalam wawancaranya mengatakan bahwa subjek DOK-2 tidak mengetahui jawaban yang sebenarnya seperti apa karena belum ada cross-check dengan dosen yang bersangkutan. Namun, subjek DOK-2 sudah mencoba menjawabnya dengan baik meskipun belum tepat. Indikator terakhir atau keempat ini merupakan kesimpulan yang diperoleh setelah melaksanakan indikator-indikator sebelumnya. Terlihat pada lembar jawab bahwa subjek DOK-2 telah menuliskan kesimpulan yang cukup baik tetapi subjek DOK-2 menuliskan jawaban yang salah. Subjek DOK-2 tidak dapat menyelesaikan permasalahan dengan baik karena subjek DOK-2 tidak melakukan pengecekan ulang sebelum mengumpulkan lembar jawabnya. Oleh karena itu, subjek DOK-2 dianggap tidak mampu memenuhi indikator keempat yaitu melihat kembali.

Berdasarkan hasil wawancara dengan subjek DOK-1 dapat dilihat 
bahwa kemampuan pemecahan masalah subjek DOK-2 dalam melaksanakan dan melihat kembali masih terdapat kesalahan. Subjek DOK-2 mengaku bingung dalam wawancaranya karena subjek DOK-2 sudah memahami maksud yang disampaikan soal sehingga merasa bahwa strategi yang digunakan sudah tepat namun jawaban yang ia peroleh ternyata hanya mendapat skor minimum. Hal ini sejalan dengan penelitian yang dilakukan oleh (Sukoriyanto, Nusantara, Subanji, \& Chandra, 2016) bahwa meskipun siswa sudah memahami masalahnya, tetapi mereka menemukan kesulitan dalam menentukan strategi apa yang harus digunakan dalam menyusun rencana penyelesaian yang kemudian dapat berpengaruh pada hasil penyelesaian seperti yang dilakukan oleh subjek DOK-2 di mana ia sudah benar dalam memilih teori namun dalam mengaplikasikannya masih terdapat kesalahan. Selain itu, subjek DOK-2 mengatakan bahwa dirinya lupa dengan beberapa teori yang telah diajarkan dosen sehingga dalam melaksanakan penyelesaian tidak cukup maksimal. Sesuai dengan penelitian yang dilakukan oleh (Wigati \& Sutriyono, 2018) bahwa kemampuan otak kiri hanya mengingat atau menyimpan memori yang sifatnya jangka pendek. Oleh karena itu, apabila hanya otak kiri yang dominan maka ada kemungkinan peserta didik dalam menyerap pelajarannya lebih mudah lupa sehingga dalam hal ini subjek DOK-2 harus selalu mengulang materi yang telah dipelajari agar dapat menutupi kekurangan yang dimiliki oleh orang dengan dominan otak kiri.

\section{b. Soal Nomor 2}

Hasil pekerjaan subjek DOK-2 dalam menyelesaikan soal geometri bidang nomor 2 ditunjukkan oleh Gambar 6 dan 7.

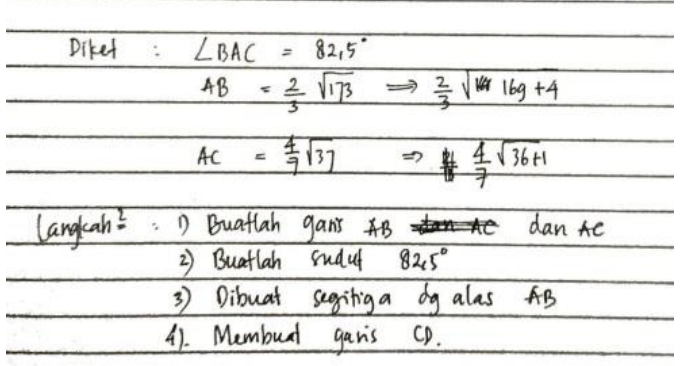

Gambar 6. Hasil pekerjaan subjek DOK-2 nomor 2 bagian A

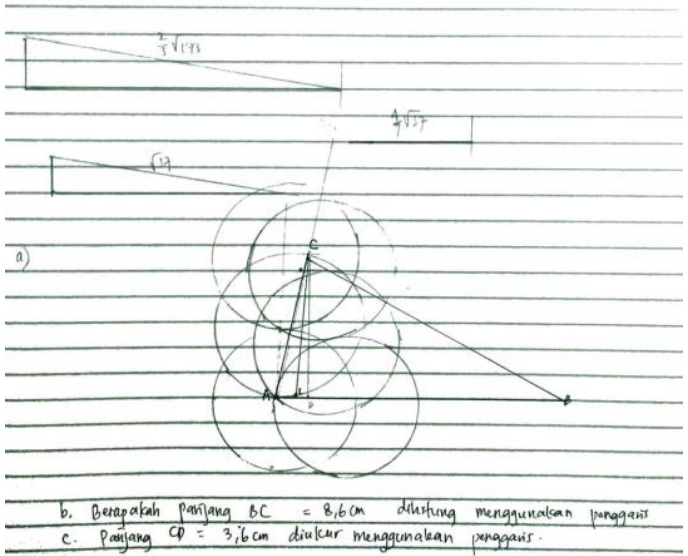

Gambar 7. Hasil pekerjaan subjek DOK-2 nomor 2 bagian $B$

Berdasarkan Gambar 6 yang merupakan hasil pekerjaan subjek DOK-2 yang berisi informasi-informasi penting terkait soal berupa hal-hal yang diketahui tetapi tidak menuliskan halhal ditanyakan. Subjek DOK-2 menuliskan hal yang diketahui berupa besar sudut dan panjang garis yang masih dalam bentuk akar. Namun, subjek DOK-2 mampu menjabarkan bentuk akar yang merupakan panjang sisi yang diketahui ke dalam bentuk yang lebih sederhana dan mudah digambar. Subjek DOK-2 dalam wawancaranya mampu memahami permasalahan pada soal dengan baik meskipun ia tidak menuliskan informasi yang ditanyakan ke dalam lembar jawabnya. Oleh karena itu, subjek 
DOK-2 dianggap memenuhi indikator pertama yaitu memahami masalah.

Selanjutnya, subjek DOK-2 mampu menuliskan langkah-langkah meskipun masih sederhana dan belum mendetail. Namun, jawaban yang diberikan oleh subjek DOK-2 berdasarkan langkah-langkah tersebut sangat baik bahkan mendapatkan skor yang mendekati maksimum. Seperti yang dapat dilihat pada Gambar 7 bahwa subjek DOK-2 memberikan gambaran segitiga-segitiga sederhana sebelum mencapai segitiga final. Subjek DOK-2 dalam wawancaranya mengaku kekurangan waktu untuk mengerjakan soal nomor dua sehingga hanya menuliskan sedikit langkah dalam menggambar segitiganya. Namun, subjek DOK-2 telah menyusun rencana dengan cukup baik. Oleh karena itu, subjek DOK-2 dianggap sudah mampu untuk memenuhi indikator kedua yaitu menyusun rencana penyelesaian. Subjek DOK-2 menggambarkan garis-garis yang diketahui pada soal dengan sangat epic. Subjek DOK-2 menggambarkan setiap segitiga kecil berdasarkan informasi yang diketahui yaitu sudut dan dua panjang garis di mana gambar segitiga-segitiga kecil tersebut untuk membantunya dalam menggambarkan segitiga besar yang merupakan segitiga inti yang menunjukkan hasil akhir dari soal. Oleh karena itu, subjek DOK-2 dianggap sudah mampu memenuhi indikator yang ketiga yaitu melaksanakan rencana penyelesaian.

Berdasarkan hasil wawancara dengan subjek DOK-2 dapat dilihat bahwa subjek DOK-2 tidak melakukan pengecekan ulang atau melihat kembali hasil pekerjaan. Subek DOK-2 mengaku kekurangan waktu sehingga tidak sempat untuk menuliskan kesimpulan. Seperti yang sudah diketahui bahwa untuk memenuhi tujuan pembelajaran, mahasiswa harus memenuhi keempat tahap Polya tersebut. Subjek DOK-2 dalam wawancara mengaku bahwa ia tidak mempunyai cukup waktu untuk melakukan pengecekan ulang terhadap hasil pekerjaannya. Selain itu, subjek DOK-2 juga tidak menuliskan kesimpulan terhadap hasil pekerjaannya pada lembar jawab yang ia kumpulkan. Kemampuan melihat kembali jawaban juga ditemui pada penelitian yang dilakukan oleh (Yuwono et al., 2018) bahwa dari 6 subjek hanya 3 subjek yang melakukan tahapan melihat kembali di mana pada salah satu nomor subjek tersebut tidak dapat memenuhi tahap melihat kembali karena tidak menuliskan kesimpulan pada lembar jawabnya.

Kemampuan pemecahan masalah matematika mahasiswa kelas E semester 1 Universitas Muhammadiyah Surakarta masih perlu ditingkatkan lagi bagi seluruh kelompok dominasi otak terutama untuk dominan otak kiri. Kemampuan pemecahan masalah dinilai berdasarkan empat langkah Polya dalam menyelesaikan soal geometri bidang. Langkah tersebut meliputi kemampuan memahami masalah, menyusun rencana penyelesaian, melaksanakan rencana penyelesaian, dan melihat kembali jawaban yang diperoleh. Hasil yang diperoleh berupa ketidakmampuan subjek untuk menarik kesimpulan. Berdasarkan hasil yang diperoleh diharapkan dapat dijadikan acuan dosen dalam menyampaikan materi selanjutnya yang terkait dengan geometri bidang. Dosen dapat memperbaiki kemampuan pemecahan masalah mahasiswa pada materi selanjutnya. Mahasiswa sudah mengetahui kemampuan yang dimiliki sekarang dalam menyelesaikan sebagian materi dari geometri bidang. Diharapkan mahasiswa dapat 
menjadikannya sebagai pendorong dalam meningkatkan kemampuannya pada materi berikutnya. Peningkatanpeningkatan ini diharapkan dapat menciptakan kegiatan pembelajaran yang lebih baik sehingga tercapai tujuan pembelajaran yang sesungguhnya.

\section{KESIMPULAN DAN SARAN}

Dalam penelitian ini, meskipun kedua subjek sama-sama dominan otak kiri tapi ternyata memiliki kemampuan pemecahan masalah yang sedikit berbeda. Pada soal geometri bidang nomer 1 yang diberikan, kedua subyek sama-sama mampu memahami dan merencanakan, belum mampu melaksanakan dan melihat kembali penyelesaian. Pada soal nomer 2, Subyek dominan otak kiri 1 (DOK-1) mampu menyelesaikan soal geometri bidang menggunakan langkah polya dengan baik, sedangkan Subjek DOK-2 atau mahasiswa dominan otak kiri 2 belum mampu dalam penarikan kesimpulan. Dengan demikian diperlukan strategi untuk meningkatkan kemampuan subjek dalam menarik kesimpulan berupa latihan secara terus menerus pada soal yang memerlukan analisis. Penelitian yang dilakukan masih terdapat beberapa kekurangan salah satunya pengumpulan data yang kurang memadai, oleh karena itu untuk penelitian selanjutnya diharapkan untuk mampu menutupi kekurangan tersebut.

\section{DAFTAR PUSTAKA}

Anisa. (2014). The Enchancement Of Problem Solving And Mathematical Communication Abilities Through Realistic Mathematics Education Instruction For State Junior High School Students In Garut Region Witri. Applied Microbiology and Biotechnology, 85(1), 2071-2079. https://doi.org/10.1016/j.bbapap.2 013.06 .007

Belecina, R. R., \& Ocampo, J. M. (2019). Brain Dominance , Learning Styles , and Mathematics Performance of PreService Mathematics Teachers. Atikan: Jurnal Kajian Pendidikan, 9(1), 1-14.

Demircioğlu, H., Argün, Z., \& Bulut, S. (2010). A case study: Assessment of preservice secondary mathematics teachers' metacognitive behaviour in the problem-solving process. $Z D M$ International Journal on Mathematics Education, 42(5), 493-502. https://doi.org/ 10.1007/s11858-010-0263-8

Gunawan, G. (2019). Analisis Kemampuan Pemecahan Masalah Matematis Siswa Menggunakan Model Pembelajaran Team Games Tournament Sma Muhammadiyah 1 Purwokerto. AKSIOMA: Jurnal Program Studi Pendidikan Matematika, 8(1), 83-90. https://doi.org/10.24127/ajpm.v8i 1.1731

Karlimah. (2010). Pengembangan Kemampuan Komunikasi dan Pemecahan masalah serta Disposisi Matematis Mahasiswa PGSD melalui Pembelajaran Berbasis Masalah. Pendidikan, 11(4), 51-60.

Laurens, T., Batlolona, F. A., Batlolona, J. R., \& Leasa, M. (2018). How does realistic mathematics education (RME) improve students' mathematics cognitive achievement? Eurasia Journal of Mathematics, Science and Technology Education, 14(2), 569-578. https://doi.org/10.12973/ejmste/76 959 
DOI: https://doi.org/10.24127/ajpm.v10i2.3482

Ninik, Hobri, S. (2016). Analisis Kemampuan Pemecahan Masalah Untuk Setiap Tahap Model Polya Dari Siswa SMK Ibu Pakusari Jurusan Multimedia Pada Pokok Bahasan Program Linier. The Gleaner, $1, \quad 211$. https://doi.org/10.12681/er.9602

Pujilestari. (2018). Analisis Kesalahan Siswa Dalam Menyelesaikan Soal Matematika Sma Materi Operasi Aljabar Bentuk Pangkat Dan Akar. Jisp, 2(1), 226-232.

Sukoriyanto, S., Nusantara, T., Subanji, S., \& Chandra, T. D. (2016). Students' Errors in Solving the Permutation and Combination Problems Based on Problem Solving Steps of Polya. International Education Studies, 9(2), https://doi.org/10.5539/ies.v9n2p1 1

Wigati, \& Sutriyono. (2018). Deskripsi Penggunaan Otak Kiri Dan Otak Kanan Pada Pembelajaran Matematika Materi Pola Bagi Siswa SMP. Jurnal Mitra Pendidikan, 2(1), 11-22.

Yohanes. (2012). Strategi Siswa Smp Dalam Menyelesaikan Masalah Geometri Ditinjau Dari Dominasi Otak Kiri Dan Otak Kanan. (November), 978-979.

Yuwono, T., Supanggih, M., \& Ferdiani, R. D. (2018). Analisis Kemampuan Pemecahan Masalah Matematika dalam Menyelesaikan Soal Cerita Berdasarkan Prosedur Polya. Jurnal Tadris Matematika, 1(2), 137-144. https://doi.org/10.21274/jtm.2018. 1.2.137-144 